\title{
THE EFFECTS OF TEACHING TECHNIQUE AND VOCABULARY MASTERY TOWARDS STUDENT'S WRITING SKILL (Experiment at State Vocational High Schools in Karawang)
}

\author{
Asep Darojatul Romli \\ Prodi Manajemen \\ Fakultas Bisnis dan Ilmu Sosial Universitas Buana Perjuangan Karawang, \\ asep.dj@ubpkarawang.ac.id \\ J1. HS.Ronggowaluyo, Telukjambe Timur, Karawang, Jawa Barat 41361
}

\begin{abstract}
The aim of this research is to know if there are effects of teaching technique and vocabulary mastery towards student's writing skill at State Vocational High Schools in Karawang West Java. The population of this research is all the state vocational high school students in Karawang. Meanwhile, the sample of this research is 60 students from two schools taken randomly. This research is experimental research with two factors; teaching technique using guessing song and conventional technique and vocabulary mastery. The data about vocabulary mastery and writing skill are taken through tests. It has tested the validity and reliability test. The data analysis, the researcher used SPSS (Statistical Product and Service Solution) Program version 17,00. The result of data 1) There is a significant effect of teaching technique towards student's writing skill. It is proved by Fo $=46.796$ and sig $=0.000<0.05$. 2) There is a significant effect of vocabulary mastery towards student's writing skill. It is proved by Fo $=23,625$ and sig $=0.000<0.05 .3)$ There are not significant interactive effects of teaching technique and vocabulary mastery towards student's writing skill in English. It is proved by $\mathrm{Fo}=1.588$ and $\mathrm{sig}=0.213>0.05$.
\end{abstract}

\section{A. INTRODUCTION}

\section{Background of the Research}

The objective of English teaching at Vocational high school is the ability to write English. But in the reality, so many students are not able to write. Commonly they only 
have capability in listening, reading and speaking. We can find this problem in almost all English classes.

Writing, although it is a complicated skill, is definitely a skill that the language teacher must teach to their students. Writing is very important since it is a process of building and sharing meaning through the usage of verbal and non-verbal symbols (Bailey \& Savage, 1994 in Lazaraton, 2001). Moreover, teaching writing should improve students' communicative skills and learn how to use the language (Richards, 2008). However, writing in English is still a problem for most Indonesian students although they have studied English from the elementary school. Only a few of them have good ability in writing.

Students' good ability to write in English is one of the main goals, which are stressed on in the teaching of English in Indonesia. Writing has a great challenge in the teaching and learning activities in high school of which as second or foreign language (Brown, 1994 in Lazaraton, 2001). Therefore, it can be assumed that the objective of writing component in language syllabus is to enable the students to write the target language (Hughes, 2002: 48). Even writing, in their first language, is an ability the students acquire naturally; but it has to be taught. This means that if the EFL learners are not taught how to write in the foreign language, their writing skills will be left behind (Morley, 2005). However, teaching writing is not considered only teaching how to spell and memorizing dialogue through the text available in the textbook, but the learners should also see the other method used in learning writing. One of the useful techniques is guessing song (role play).

Nowadays, many teachers thought that students should learn to write the language by interacting to others. For this case, students should master several writing components, such as comprehension, pronunciation, grammar, vocabulary, and fluency (Richard \& Renandya, 2000). In brief, English teacher should be creative in developing their teaching learning process to create good atmosphere, improve the students writing skill, give attention to the writing components, and make the English lesson more exciting.

\section{B. THEORITICAL FRAMEWORK AND HYPOTHESIS}

\section{Review of Related Literature}

\section{Nature of Writing}

Writing is one of language skill that needs kind of practice, such as how to use the words correctly, what the words mean, and so on. Writing is correcting the words in 
order to express to the reader whether the writer is alert and enthusiastic or not, when the writer wants to communicate his or her ideas.

The ability to write a language fluently and to understand it when it is spoken by native writer is the kind of competence that is most value and designed with reading and writing being important secondary goals. Therefore, it is very difficult for foreign language learners to write in the target language so it means that learning how native writer write the language in the real communications is needed.

R Jones (1998:14) state that "Writing is a form of communication so it is important that you say is conveyed in the most way". In the Webster's Ninth New Colligate Dictionary, Writing is defined as: 1) to utter words or articulate sound with the ordinary voice; 2) to express the thought, opinion or feeling orally. Therefore, Writing is one of the ways to send message from our mind to other people orally.

\section{Writing Skill}

Basically the purpose of Writing is to inform or to communicate what is in our mind to others, therefore, communication is very fundamental thing to human existence in life. While communication is an exchange of information of thought and ideas, the expression of one's desire, needs, efforts, etc, orally. Writing as a means of communication influences the way of our individual life (Anderson, 1969: 36). Alwasilah (1993: 8) explains that communication process will involve (1) a person who is communicating, (2) information which is being communicated, and (3) a means of communication. None of the communication without involving these three aspects and truly a man is difficult to escape from the three aspects.

Writing is the most priority of productive skill besides listening. It cannot be separated from the listening; it relates to decoding message that call for as active participant. Listening is actually receptive skill but it is involved in understanding the message conveyed, as it is said by Finocchiaro, M, and Bonomo (1973: 106) that listening and Writing are interdependent in general, but it is not automatically improving listening comprehension and Writing ability. However, a writer may write with a certain degree of fluency and speed.

\section{Nature of Vocabulary}

Writing of vocabulary mastery, the first thing that should be explained is the definitions of mastery since the primary goal of vocabulary, which is mastery. 
According to Allen (2000:856), Mastery is skill or knowledge that makes one master of a subject. The Heinemann Dictionary (1989:631) also defines that mastery is the skill or knowledge of master. From the definitions stated previously, mastery is someone's skill or knowledge of a subject. Subject in this case is vocabulary in a foreign language, which is learnt by students. In addition, Harmer (2002:13) points out that without grammar very little can be conveyed, without vocabulary nothing can be conveyed. Meaning that the assistance of vocabulary cannot be separated by the existence of a language. In other words, no language exists without vocabulary.

Vocabulary in Oxford: Advanced Learner's Dictionary (1995:1331) the definition of vocabulary is : (1) The total number of words in a language, (2) All the words known to a person or used in a particular book, subject, etc, (3) a list of words with their meanings, especially one that accompanies a textbook in a foreign language.

In the World Book Encyclopedia (1995:414) vocabulary is the total number of words in a language, it is also to collection of words and a person knows and uses in Writing or writing. Furthermore, Read (2000:11) say a basic assumption in vocabulary is knowledge of words. A word is a microcosm of consciousness. Vocabulary therefore has an important role to help the students understand the meaning of words.

\section{Vocabulary Mastery}

According to Thornbury (2002:3-9), there are some ways of presenting a word meaning namely :

a) Word classes; the words play different roles in a text. They fall into one of eight different word classes such as nouns, pronouns, verbs, adjectives, adverbs, prepositions, conjunctions, and determiner.

b) Word families; how words may share the same base or root but take different endings. A word family comprises the base word plus its inflexions and its most common derivatives. $($ e.g. play + er $=$ player, $r e+$ play $=$ replay, play + ful $=$ playful $)$

c) Collocations; how words "couple up" to form compounds, and how they "hunt in packs" in the shape of multi-word units. It is seen as part of a continuum of strength of association: a continuum that moves from compound words (second-hand, record player), through multi-word units - or lexical chunks - (bits and pieces), including idioms (out of the blue) and phrasal verbs (do up), to collocations of more or less fixedness (set the record straight, set a new world record). 
d) Synonyms; Words that share a similar meaning. Thus: old, ancient, antique, aged, elderly are all synonyms in that they share the common meaning of not young/new. Synonyms are similar, but seldom the same.

e) Antonyms; words with opposite meaning - like old and new.

\section{Nature of Teaching Technique}

Teaching technique is the way to get the goal of learning. Teaching Writing is also teaching in order to make the learner has the Writing skill. Writing skill is regarded by many language learners as the measure of knowing a language. Getting a communicative activity in the process of teaching and learning is very important. The teacher should know and provide also create communicative material in order to make the student feels interested in learning English.

The material is the important thing in teaching and learning activities. The teacher should know the criteria of communicative material and consider the materials which are appropriate for the learners. Richard and Rogers (1986:25) stated in "Approaches and Method in Language Teaching" were specified the role of instructional material within a functional or communicative methodology in term : 1)Material will focus on the communicative abilities of interpretations, expressions, and negotiations; 2) material will focus on understandable, relevant, and interesting exchange information, rather than on the presentation of grammatical form; 3) material will involve different kinds of texts and different media, which the learners can use to develop their competence through a variety different activities and tasks.

\section{THE RESEARCH FINDING AND DISCUSSION}

\section{The Description of Data}

This research is experimental research with two factors; firstly is teaching techniquefactor(A) and secondly is vocabulary mastery factor (B). There are sub factors of each factor that is called level. There are two levels of teaching technique factor that is experimental level with guessing song $\left(\mathrm{A}_{1}\right)$ and the second level is conventional technique $\left(A_{2}\right)$. Furthermore, the second factor is vocabulary mastery with two levels. Firstly is high vocabulary mastery $\left(B_{1}\right)$ and the secondly is low vocabulary mastery $\left(B_{2}\right)$. The result of calculation in this research can be seen as the following table: 


\section{Descriptive Statistics}

Dependent Variable:Writing Skill

\begin{tabular}{|ll|l|l|l|}
\hline KemampuanVM & $\begin{array}{l}\text { TeachingTechni } \\
\text { que }\end{array}$ & Mean & Std. Deviation & N \\
\hline High VM & Guessing Song & 85.3333 & 8.12111 & 15 \\
& TPR & 74.0000 & 7.36788 & 15 \\
& Total & 79.6667 & 9.55324 & 30 \\
\hline Low VM & Guessing Song & 70.3333 & 7.18795 & 15 \\
& TPR & 63.6667 & 5.81460 & 15 \\
& Total & 67.0000 & 7.26351 & 30 \\
\hline Total & Guessing Song & 77.8333 & 10.72247 & 30 \\
& TPR & 68.8333 & 8.37518 & 30 \\
& Total & 73.3333 & 10.56323 & 60 \\
\hline
\end{tabular}

Statistic Description of Research Planning

\begin{tabular}{|c|c|c|c|c|}
\hline \multirow{2}{*}{$\mathrm{B}$} & \multirow{2}{*}{ Stat } & \multicolumn{2}{|c|}{$\mathrm{A}$} & \multirow{2}{*}{ Total } \\
\cline { 2 - 5 } & & $\mathrm{A}_{1}$ & $\mathrm{~A}_{2}$ & \\
\hline \multirow{3}{*}{$\mathrm{B}_{1}$} & $\mathrm{n}$ & 15 & 15 & 30 \\
\cline { 2 - 5 } & $\overline{\mathrm{x}}$ & 85.33 & 74 & 79.67 \\
\cline { 2 - 5 } & $\mathrm{S}$ & 8.12 & 7.37 & 7.74 \\
\hline \multirow{3}{*}{$\mathrm{B}_{2}$} & $\mathrm{n}$ & 15 & 15 & 30 \\
\cline { 2 - 5 } & $\overline{\mathrm{x}}$ & 70.33 & 63.67 & 67.00 \\
\cline { 2 - 5 } & $\mathrm{S}$ & 7.19 & 5.81 & 6.50 \\
\hline \multirow{3}{*}{ Total } & $\mathrm{n}$ & 30 & 30 & 60 \\
\cline { 2 - 5 } & $\overline{\mathrm{x}}$ & 77.83 & 68.83 & 73.33 \\
\cline { 2 - 5 } & $\mathrm{S}$ & 7.655 & 6.59 & 7.12 \\
\hline
\end{tabular}

Keterangan :

A : Teaching Technique

$A_{1} \quad$ : Guessing Song

$\mathrm{A}_{2} \quad$ : Conventional Technique 


\section{B : Vocabulary Mastery \\ $\mathrm{B}_{1} \quad$ : High Vocabulary Mastery \\ $\mathrm{B}_{2} \quad$ : Low Vocabulary Mastery}

Based on this data, table 4.2 showed that is experimental class $\left(A_{1}\right)$ has mean score 77,83 , it is bigger than control class that has mean score 68,83 . In this description showed that experimental class is successfully. Then, if it saw from vocabulary mastery, it showed that students with high vocabulary mastery have bigger score than students with low vocabulary mastery. The student's high vocabulary mastery has mean score of result learning (writing skill) is 79, 67, while the group of students with low vocabulary mastery have mean score of result learning (writing skill) is 67,00, it showed the expected result of the research.

Hereinafter, this case can be called how comparison of mean score in result learning (writing skill) isbased on research levels. In other words, it can be made matrix $2 \times 2$ or $\left\{A_{1}, A_{2}\right\} \times\left\{B_{1}, B_{2}\right\}$. In order to be clearly, we used data statistic on the table 4.2. From that table showed that is column $\mathrm{A}_{1}$ row $\mathrm{B}_{1}$ or experimental column using guessing song technique $\left(\mathrm{A}_{1}\right)$ and high vocabulary mastery $\left(\mathrm{B}_{1}\right)$ with 15 students have mean score of result learning (writing skill)is 85,33. If this group is compared with the group of $A_{1} B_{2}, A_{2} B_{1}$ and $A_{2} B_{2}$, it showed that the group of experiment $A_{1} B_{1}$ has highest score. The lower score is $\mathrm{A}_{2} \mathrm{~B}_{1}$ or control group using teaching technique and it has high vocabulary mastery with mean score 74 . Then, the next is $A_{1} B_{2}$ or experimental group using guessing songteaching technique and it has low vocabulary mastery with mean score 70,33 . The last group is group of $\mathrm{A}_{2} \mathrm{~B}_{2}$ or control group using teaching technique and it has low vocabulary mastery with mean score 63,67.

In data of table 4.2 showed there is interesting fact that is mean score of experimental group $\left(\mathrm{A}_{1} \mathrm{~B}_{2}\right)$ or writing skillscore using guessing songteaching technique and student's low vocabulary mastery has lower score than mean score of control group $\left(\mathrm{A}_{2} \mathrm{~B}_{1}\right)$ orwritingskillscore of group using teaching technique and student's high vocabulary mastery has higher score.

\section{A. Requirement Test of Data Analysis}

Before doing hypothesis test, it is needed to do analysis condition test which is covered normality test and homogeneity test firstly.

\section{Normality Test}


Normality test of dependent variable or covariate variable is needed. It is function to measure the method; is parametric statistic method or non-parametric statistic method. If the collecting data follows a normality test or other theory distribution test, so it can be continued to analysis parametric statistic. Then, parametric statistic will be done with analysis of variants (ANOVA) or it used general linier model (GLM) analysis.

The analysis result data of normality test about writing skill using SPSS program can be seen on the following table :

Normality test using Statistic Test

\section{One-Sample Kolmogorov-Smirnov Test}

\begin{tabular}{|c|c|c|c|}
\hline & & $\begin{array}{l}\text { Guessing } \\
\text { Song }\end{array}$ & TPR \\
\hline $\mathrm{N}$ & & 30 & 30 \\
\hline Normal Parameters ${ }^{\mathrm{a}, \mathrm{b}}$ & Mean & 77.8333 & 68.8333 \\
\hline & Std. Deviation & 10.72247 & 8.37518 \\
\hline Extre & Absolute & .138 & .143 \\
\hline Differences & Positive & .134 & .143 \\
\hline & Negative & -.138 & -.103 \\
\hline Kolmogorov-Smirnov & & .758 & .784 \\
\hline Asymp. Sig. (2-tailed) & & .614 & .571 \\
\hline
\end{tabular}

a. Test distribution is Normal.

b. Calculated from data.

Based on table 4.3 showed that learning result of English for writing material which is using guessing song teaching technique and $\left(\mathrm{A}_{1}\right)$ and teaching technique $\left(A_{2}\right)$ even student's high vocabulary mastery $\left(B_{1}\right)$ or student's vocabulary mastery $\left(\mathrm{B}_{2}\right)$ is normal.The score of statistic test Kolmogorov Smirnov Z (KS)for learning result of English especially writing material from guessing song teaching technique is 0,758 and $\operatorname{sig}=0,614>0,05$, it means that writing skill data using guessing song teaching technique is normal. Meanwhile, KS statistic test for learning result of English especially writing material from TPR teaching technique is 0,784 and sig $=$ $0,571>0,05$, it means that writing skill data using teaching technique is normal. 


\section{Homogeneity Test}

In difference analysis, beside it has to fulfill assumption that the data comes from normal population, it has to fulfill variants homogeneity assumption.Homogeneity test aims know is variants come from homogeny of population.Homogeneity test from student's learning result data (writing skill) is done with Levence Test in significance degree 0,05 .

\section{Homogeneity Test for Writing Skill}

\section{Levene's Test of Equality of Error Variances ${ }^{a}$}

Dependent Variable:WritingSkill

\begin{tabular}{|c|c|c|c|}
\hline F & df1 & df2 & Sig. \\
\hline .387 & 3 & 56 & .763 \\
\hline
\end{tabular}

Tests the null hypothesis that the error variance of the dependent variable is equal across groups.

a. Design: Intercept + KemampuanVM + TeachingTechnique + KemampuanVM * TeachingTechnique

To homogeneity test, it is raised the hypothesis as follows :

$\mathrm{H}_{0} \quad$ : The data comes from homogeny of population

$\mathrm{H}_{1} \quad$ : The data does not come from homogeny of population

The criteria :

If sig score (levene's test) $>0,05$; so $\mathrm{H}_{0}$ is accepted and $\mathrm{H}_{1}$ is rejected. On the contrary, if sig score (levene's test) $<0,05$; so $\mathrm{H}_{1}$ is accepted and $\mathrm{H}_{0}$ is rejected.

Homogeneity test using SPSS in learning result data (writing skill) on Table 4.4 showed that each Fohas 0,387 andSighas 0,763. Therefore, the sig score is 0,763>0,05, thereby $\mathrm{H}_{0}$ is accepted and $\mathrm{H}_{1}$ is rejected. So, it can be summarized that the data comes from homogeny of population.

\section{B. The Test of Research Hypothesis} ANOVA Test 2 Ways 
Analysis of Variants or ANOVA is some technique to multivariate analysis which is function to differentiate of mean score more than two data group with comparison each variants way.Variants analysis is belong to parametric statistic category. As the tool of parametric statistic, in using ANOVA calculation has to do assumption test first which is covered Normality and homogeny. After assumption test above is up to standard of this research, so it can be tested of Anova 2 direction.

\section{The First Hypothesis Test :}

There is significant effect of using guessing song teaching technique towards student's writing skill.

The hypothesis is tested with significance coefficient value. If sig score $>0,05$; so $\mathrm{H}_{0}$ is accepted and $\mathrm{H}_{1}$ is rejected. On the contrary, if sig score $<0,05$; so $\mathrm{H}_{0}$ is rejected and $\mathrm{H}_{1}$ is accepted.

From the test aboveusing SPSS 17 program obtained sig for the ability to speak English Fo $=46.796$ and sig $=0.000<0.05$, therefore we can conclude that there is a significant effect of using guessing song teaching techniquetowards writing skill. And it can also be seen or proven in meandifference ability to speak English is taught using guessingsong and teaching techniques students taught using teaching techniques are significantly different. Students who are taught by guessing song teaching technique $\left(\overline{\mathrm{X}} \mathrm{A}_{1}=77,83\right)$ have the ability to speak English (Writing Skill) is higher than students taught with conventional teaching technique $\left(\overline{\mathrm{X}} \mathrm{A}_{2}=68.83\right)$

\section{The Second Hypothesis Test :}

There is a significant effect on the ability of vocabulary mastery towards writing skill.

According to the table ANOVA (SPSS output) shows that the value of Fo = 23,625 and sig $=0.000<0.05$, then $\mathrm{H} 0$ is rejected and $\mathrm{H} 1$ is accepted, thus it can be concluded there is the effect of the vocabulary mastery towards student's writing skill.

And it can also be seen or proven in mean difference ability to speak English for students who have English language vocabulary skills with students who have high English vocabulary skills differ significantly lower.Student's high vocabulary mastery $\left(\overline{\mathrm{X}} \mathrm{B}_{1}=79.67\right)$ has the ability to speak English is higher than student's low vocabulary mastery $\left(\overline{\mathrm{X}} \mathrm{B}_{2}=67.00\right)$ 


\section{Third Hypothesis Test:}

There are not significant effects of using guessing song teaching technique and vocabulary mastery towards student's writing skill.

According to the table ANOVA (SPSS output) shows that the value of Fo = 1.588 and sig $=0.213>0.05$, then $\mathrm{H} 0$ is accepted and $\mathrm{H} 1$ is rejected. This suggests that the interaction of teaching techniques (guessing song) and vocabulary mastery towards student's writing skill is not significant. Adjusted $R$. equal to 0.539 , it means that squared variability spoken English which can be explained by the variable guessing song teaching techniques, vocabulary mastery and interaction between guessingsong techniques and vocabulary mastery by $53.9 \%$.

Based on the ANOVA results, it appears that the interaction between song guessing teaching technique and vocabulary mastery are no significant interactions. In the absence of interaction, then no further analysis to see the simple effect between subgroups such interaction the factors that build.

\section{Interpretation of Research Result}

According to analysis result above, it can be interpreted as follows:

1. This experimental research two factors are teaching technique factor and vocabulary mastery factor. Each factor consists of two levels that is experimental level using guessing song teaching technique in SMKN 1 Karawang and control level using conventional teaching technique in SMKN 1 Rawamerta, while vocabulary mastery factor consists of high vocabulary mastery level and low vocabulary mastery level. The data description showed mean score of experimental group (writing skill) is higher than control group mean score. The score of experimental group is 77,88 , while the score of control group is 68,83 .

Result observation in the field is found there is indication that student always use mother language in the English class, so that habitual always do while they are in the class. In sum, at English time when the teacher used conventional technique where the teacher is active and student is passive, it was becoming boring class. Students were not spirit in learning and make them sleepy. In this case, it needs a innovation teaching technique. Some of innovation teaching technique and make them interesting in learning that is using guessing song technique. Guessing Song is some of teaching technique while singing. This technique is based on direct learning 
model; that much experience leaved from perception and to remember behavior is a model, and then tried to copy through tuition by the teacher. The teacher has to make a learning theme through English songs. And or English song is available, and it is according to the learning theme, so that it becomes a learning media. In guessing song, students will get a new vocabulary indirectly. They are trained the pronunciation of English so that they could to improved their ability of English well. From last explanation can be concluded that writing skill can be influenced by guessing song teaching technique.

2. The research hypothesis test using ANOVA 2 direction on three hypothesis showed that the first and the second hypothesis have same sig score that is 0,000 . With the value of $0,000<0,05$, so $\mathrm{H}_{0}$ is rejected and $\mathrm{H}_{1}$ is accepted. It means that there is significant effect of using guessing song teaching technique towards speaking skill and there is significant effect of vocabulary mastery towards writing skill is accepted.

This phenomenon showed that writing skill will improve when the students have high vocabulary mastery. High or low of vocabulary mastery which is had by students is influenced by internal and external factor. Internal factor can come from talent, enthusiasm, intelligence, and so on. The talent and enthusiasm factor are most domain factor that become students have high or low vocabulary mastery. When enthusiasm in English was high, that they will move to get much vocabulary of English. Although talent and enthusiasm as internal factor is important, but external factor also is necessary to lead them in getting vocabulary of English. Some of external factor is leading and motivation by the teacher where he/she teaches English subject could make student's vocabulary mastery higher. Because of if the students have much vocabulary of English, so they could speak English well.

3. Meanwhile, the third result of statistic hypothesis showed the sig value is 0,213. With the value of $0,213>0,05$, so $\mathrm{H}_{0}$ is accepted and $\mathrm{H}_{1}$ is rejected. It means that the statement of there are effects of using guessing song teaching technique and vocabulary mastery towards student's speaking skill is rejected. Based on the ANOVA results, it appears that the interaction between song guessing teaching technique and vocabulary mastery are no significant interactions. In the absence of 
interaction, then no further analysis to see the simple effect between subgroups such interaction the factors that build.

\section{Conclusion}

Based on data description and data analysis can be concluded as follows :

1. There is a significant effect of teaching technique towards student's writing skill. It is proved byFo $=46.796$ and sig $=0.000<0.05$.

2. There is a significant effect of vocabulary mastery towards student's writing skill. It is proved by $\mathrm{Fo}=23,625$ and sig $=0.000<0.05$.

3. There are not significant interactive effects of teaching technique and vocabulary mastery towards student's writing skill in English. It is proved by Fo $=1.588$ and sig $=$ $0.213>0.05$.

\section{Implication}

Based on the calculation, the implications of teaching technique (X1) and Vocabulary mastery (X2) towards student's writing skill (Y) are in the following.

1. Teaching technique is the way to get the goal of learning. Teaching writing is also teaching in order to make the learner has the writing skill. Writing skill is regarded by many language learners as the measure of knowing a language. Getting a communicative activity in the process of teaching and learning is very important. The teacher should know and provide also create communicative material in order to make the student feels interested in learning English. Teaching technique of writing is influenced by factors such as interest, motivation, and environment. To build student's interest in learning writing, the teacher has to make the interesting teaching technique. So many techniques to teach writing in the classroom. One of this is a role play technique. In conducting the $t \epsilon 75$ of writing by using role-play, the students require being familiar with exactly what the situation is, and they require to be given sufficient information about the background for them to function properly. In order to make teaching and learning process can be more effective. The guessing game is choose as the method in teching writing. In this game the song is used as the object that must be guessed by the student.

2. Vocabulary mastery is one of the substantial components in writing. By having adequate vocabulary mastery, a student is able to speak English well. The vocabulary 
mastery can be enriched by giving a test to the student about words implementation, labeling a word to a picture, describing someone, guessing the song title, and finding out the synonym or antonym from the text. Mastery vocabulary can be enhanced through many ways such as reading, constructing a meaning, looking a dictionary up, surfing on the internet, watching western movies and listening to western music. Furthermore, the more student try to speak English, the wider vocabulary mastery he or she will obtain. It will be automatically determined student's writing skill.

\section{Suggestions}

Based on explanation of research result, the researcher suggest in this paper as follows :

1. To become students more active in communication of English is necessary the variation of technique and method of teaching. In order to teaching is innovative, so this technique (guessing song) can use in the classroom.

2. The teachers have to make the learning theme through English song. And or English song is available, and it is according to the learning theme, so that it becomes a learning media.

3. To make students active in the classroom, the teachers are not only beginning in the interesting class but also he/she has to make the class becoming happy class.

4. High or low of vocabulary mastery which is had by students is influenced by internal and external factor. Internal factor can come from talent, enthusiasm, intelligence, and so on. The talent and enthusiasm factor are most domain factor that become students have high or low vocabulary mastery. When enthusiasm in English was high, that they will move to get much vocabulary of English. Although talent and enthusiasm as internal factor is important, but external factor also is necessary to lead them in getting vocabulary of English. Some of external factor is leading and motivation by the teacher where he/she teaches English subject could make student's vocabulary mastery higher. Because of if the students have much vocabulary of English, so they could speak English well.

\section{BIBLIOGRAPHY}

Arikunto Suharsimi. 2006. Prosedur Penelitian Sebagai suatu Pendekatan Praktek. Jakarta: RinekaCipta. 
Brown H.D. 1994. Teaching by Principles :An interactive Approach to Language Pedagogy. New Jersey: Prentice Hall Regents.

David Haris. 1979. Testing Writing as a Second Language. New York: Hill Book Company.

Dimas Irwan. 2003. PintarPercakpanBahasaInggris. Surabaya: Amanah.

Fritz W. Scharpf. 1989. Epistemic Logic and the Theory of Games and decisions. New York:

Kluwer Academic Publisher

Fraenkel, Jack R and Norman. 2003. How to Design and Evaluate Research in Education. McGraw-Hill.

Gerard Varet. 1985. Games Real Actor Play. New York: Kluwer Academic Publisher.

Hornbury, A.S. 1995. Oxford Advanced Learner's Dictionary. New York: Oxford University Press.

Harmer, Jeremy. 2002. How to Teach Vocabulary. England: Longman.

Hamzah B. Uno. 2008.Model Pembelajaran. Jakarta: BumiAksara.

Ilzamudin Ma'mun. 1990. An Ontology of TEFL. Jakarta: BumiAksara

Jack C. Richards and Theodore S. Rodgers. 1986. Approaches and Methods in Language Teaching. Cambridge: Cambridge University.

Jonea Rhori. 1989. Writing \&Listening. London: John Murry Published Ltd.

Kurikulum Tingkat SatuanPendidikan. 2006. Jakarta: Depdiknas.

Katherine, Harber and Pyton, Geofrey. 1989. Heinemann English Dictionary.New Edition.

Oxford: Heineman Educational. 